\title{
Assessing Natural Resource Use Conflicts in the Kogyae Strict Nature Reserve, Ghana
}

\author{
Eric Oduro-Ofori ${ }^{1}$, Kafui A. Ocloo ${ }^{1}$, Charles Peprah $^{1} \&$ Gilbert Effah $^{1}$ \\ ${ }^{1}$ Department of Planning, Kwame Nkrumah University of Science \& Technology, Kumasi, Ghana \\ Correspondence: Eric Oduro-Ofori, Department of Planning, Kwame Nkrumah University of Science \& \\ Technology, Kumasi, Ghana. E-mail: odurooforieric@yahoo.com, eoduro-ofori.cap@knust.edu.gh
}

\author{
Received: July 15, 2015 Accepted: July 24, 2015 Online Published: July 27, 2015 \\ doi:10.5539/enrr.v5n3p56 URL: http://dx.doi.org/10.5539/enrr.v5n3p56
}

\begin{abstract}
This study assessed the type, origin, nature, level and the effect of the conflicts on the development of the Kogyae Strict Nature Reserve (KSNR) in Ghana. It also examined constraints confronting effective conflict management in KSNR and made policy recommendations to help curtail the conflicts. Data for the study were obtained through interviews with the stakeholders as well as on-site observation. The results revealed that structural conflict was the major type of conflict characterizing the conflicts in the KSNR. This conflict mainly originated from weak enforcement of resource laws, absence of conflict management mechanism, land litigation and demographic changes. These together with inadequate source of livelihood and imposition of policy without effective participation of stakeholders have increased illegal activities including hunting and encroachment, resulting in uncontrolled conflicts in the KSNR. The study recommends that the Ministry of Lands and Natural Resources establishes a legislative instrument to put in place a well-structured conflict mechanism to address conflicts in natural resource areas. In the short term, regular conservation education programmes should be embarked on in the fringe communities for the people to appreciate the need for natural resource sustainability.
\end{abstract}

Keywords: conflicts, Ghana, Kogyae, natural resource use, nature reserve

\section{Introduction}

People everywhere on the globe compete for natural resources to enhance their livelihoods. These natural resources normally include land, water, forest, rangelands and others that have the ability to help enhance and sustain livelihoods (Anderson et al., 1996; Ayling \& Kelly, 1997). Also many poor households in Africa, Latin America as well as Asia depend to a greater extent on common pool resources for their livelihood and food supply (Buckles \& Rusnak, 2005; Sunderlin et al., 2005).

According to Hammill and Bescançon (2010), natural resources represent different things to different groups. The demand for these natural resources at times leads to conflicts that need to be managed. The demand for such natural resources has led to several conflicts among stakeholders such as local communities, and the Wildlife Division among others (Hagan, 1998; Levy, 2009; Ayivor, Gordon, \& Ntiamoa-Baidu, 2013). According to Atta-Asamoah, (2010), natural resource use has often led to conflicts due to the fact that it plays a pivotal role in wealth creation in society and by extension, the rise and fall of nations. Some of the main causes of natural resource conflicts include the scarcity of a natural resource; the extent to which the supply is shared by two or more groups; the relative power of those groups; the degree of dependence on this particular resource, or the ease of access to alternative sources (Engel \& Korf, 2005). Also, Nang, Khiev, Hirsch, and Whitehead (2011) indicated that some of the causes of conflicts over natural conserved areas included poor stakeholder analysis in natural resource management issues regarding lack of clarity in roles, overlapping roles, misfit between formal roles and actual practice, lack of effective feedback mechanisms and inadequate coordination and participation.

In Ghana, there are normally conflicts between communities and managers of protected areas (Ayivor et al., 2013:37). In 2006, there was a border dispute in Kyabobo National Park which resulted in the tragic death of two Wildlife Officials (Nkwanta South District Assembly, 2006 cited in Ayivor et al., 2013). Also a poacher lost his life for resisting arrest in the Bui National Park in 2007 (Ayivor, 2007 cited in Ayivor et al., 2013). On the contrary, conflict experts also recognize the value of conflict as a catalyst for positive social change. Consequently, conflict should not be altogether eliminated through resolution but rather managed so that it does not lead to violence but rather achieves change. 
The Kogyae Strict Nature Reserve (KSNR) which is the case understudy is one of the few nature reserves with great ecological potentials in Ghana. According to the Ministry of Lands and Natural Resources (2012:4), Strict Nature Reserves are 'generally, relative small areas containing fragile habitats, outstanding ecosystems or natural features in a relatively undisturbed state and which are prime representatives of the scientific study, monitoring, education or conservation of biological or cultural resources'. Such areas are to be maintained in an evolutionary dynamic state and will require strict protection with minimal human disturbance, where no management interventions will generally be permitted. Tourism, recreation and public access will be generally forbidden except for educational, scientific and cultural reasons, where only non-mechanized access will be allowed. However research indicates that despite the tacit agreements entered into with the inhabitants of the reserve, the Wildlife Division has not succeeded in getting inhabitants to pull out.

The Wildlife Division has held several consultations with the regional and district political authorities to assist in reclaiming the reserve but no solution has been achieved (Hagan, 1998). Increased competition for natural resources among multiple stakeholders with diverse interests is occurring worldwide within the current trends of globalization, democratization, decentralization and urbanization. This brings to the fore questions about the type, origin, nature, level of the conflicts; the effects of these conflicts on the society and the effectiveness of the conflict management measures in addressing these conflicts in order to ensure conservation and sustainability of the natural resources in the country.

The recent attention may reflect a growing awareness of the scope, magnitude and the assumed implications of natural resource conflicts globally. While the last two decades have seen significant advances in understanding the linkages between peace-building, poverty reduction and biodiversity conservation issues and natural resources (Warner, 2000), the influence of these linkages on conflict remains under-researched (Garrett \& Piccinni, 2012).

The extant literature on conflict in nature conserved in Ghana is limited. More so, the available ones have narrowly focused on the causes of conflicts; its effect on livelihood and providing solutions to mitigate the conflicts in protected areas (Ayivor et al., 2013). To date, the effects of conflicts on other development issues like the management and the environmental dimensions remains under researched in Ghana. Questions about the relationship, the nature, levels and the stage of conflicts and natural resources management have long been a subject of intense academic and policy discourse that has emanated in prominence since the late 1980s (Atta-Asamoah, 2010). This has affected a holistic diagnosis of the conflict situation in order to provide comprehensive interventions to address these conflicts in Ghana. As a result of the above gaps in literature with respect to Ghana, natural resource managers, policy makers and government officials largely depend on the wholesale import and reception of foreign experiences, especially the South American literature and recommended practice by international organisations for Ghanaian practice and policy formulation. The study therefore seeks to achieve the following objectives:

- To assess the type, origin, level and nature of conflicts

- To establish the effects of the conflicts on livelihoods, environment and management of the KSNR and

- To suggest recommendations to improve natural resources conflict management practices

\section{Literature Review}

\subsection{Meaning of Natural Resource}

The world is naturally endowed with natural resources although the extent of this varies from country to country. However, the concept of natural resource has become difficult to define precisely though most people and organisations have an intuitive idea of what natural resource is (Atta-Asamoah, 2013). The World Trade Organisation defined natural resources as the stocks of materials that exist in the natural environment that are both scarce and economically useful in production or consumption, either in their raw state or after a minimal amount of processing (World Trade Report, 2010). Alao (2011) describes natural resources as all non-artificial products situated on or beneath the soil, which can be extracted, harvested or used, and whose extraction, harvest or usage generates income or serves other functional purpose in benefiting mankind. Increasingly, the use of such natural resource is being recognized, both in terms of socio-economic benefits and in terms of their contribution to other aspects of human well-being, through direct and indirect use as well as non-use values.

The pressure on natural resources is however mounting due to competing demands from different users. In the past, natural resource was mainly used for domestic and agricultural purposes. The domestic water demand is increasing due to changing lifestyles caused by socio economic development. The natural resource use for agriculture is expected to increase due to its intensification to keep pace with food demand of a growing population (Joy \& Paranjape, 2009). New demands are emerging from sub-sectors such as hydropower and other 
industries. Power differences between groups competing for use can be enormous and the interests are a matter of survival (Buckles \& Rusnak, 2005).

There are several users of natural resources (such as governments, business, industry, landowners, unions, rebel forces, international corporations, international organizations, and non-governmental organizations) with their corresponding varying interests either for extraction, management and trade of natural resources (Ramírez, 1999). According to Ayling and Kell (1997), these many stakeholder interests and actions concerning natural resources can have both direct and indirect bearing on conflict dynamics and the potential for escalation or resolution. A research work by Roe, Nelson and Sandbrook, (2009) have indicated that conflict between local groups and other more powerful actors, including both state agencies and private sector investors, remains widespread and is often intensifying.

\subsection{Conflict in Natural Resources Uses}

Conflict is endemic to all social life. It is an inevitable part of living because it is related to situations of scarce resources, division of functions, power relations and role-differentiation (Bercovitch, 1983:104). The concept has therefore acquired a multitude of meanings and connotations making it a semantic jungle. The physical sense of two or more bodies moving against each other has often been retained by those who offer an empirical definition of conflict (Bercovitch, Kremenyuk, and Zartman, 2008: 4).

For this purpose, it is imperative in this study to consider what other researchers perceive natural resource conflicts to be. The Food and Agriculture Organization of the United Nations (2000) describes Natural Resource Use Conflict as: "Disagreements and disputes over access to, and control and use of, natural resources. These conflicts often emerge because people have different uses for resources such as forests, water, pastures and land, or want to manage them in different ways". Schweithelm, Kanaan and Yonzon, P., (2006) also defined natural resource conflict as situations where the allocation, management, or use of natural resources results in violence, human rights abuses, denial of access to natural resources to an extent that significantly diminishes human welfare. These definitions imply that disagreements arise when interests and needs are incompatible, or when the priorities of some user groups interfere with the interests of other users or better still are not considered in policies, programmes and projects.

\subsubsection{Types of Conflict}

A typology approach attempts to classify conflicts into predictable groups or patterns. The core elements or idea supporting such classification is to begin to find out and to understand the root causes of a conflict in order to propose resolution strategies that will have a higher probability of success (EU-UN, 2012; Engel and Korf 2005:185-187; Moore, 1996). Five types of conflicts have however been established in literature namely data conflict, interest conflict, value conflict, relationship conflict and structural conflict.

According to Moore (1996) data conflict is that type of conflict which arises when information is lacking, differently interpreted or withheld by one party from the other party. Related research in natural resources areas by Engel and Korf (2005:185-187), indicate that data conflicts may arise when for example hunters begin to question how the birds are endangered by their activities and villagers have no access to information on the proposed restriction of the boundaries of the protected areas of the natural resources. Interest conflict in natural resource areas occurs when there is perceived variance in interests related to utilization of the forest resources. And again, when there are perceived threats of the forest guards attempt to restricting access to needed resources by the community members.

Value conflict has also been observed in most natural resources areas. According to EU-UN, (2012) value conflict is mostly underpinned by issues of differences in people's ways of life, deep rooted goals or varying criteria on how to evaluate behaviours. And in the case of natural resources conflicts, issues such as Forest officers' lack of appreciation for the ceremonial importance of certain natural resources (bird feathers) in determining relationships within villages have been the a major point where conflicts have sparked (Engel and Korf, 2005).

Relationship conflict in natural resource areas are said to prosper in environments of strong emotions, stereotypes, poor communication and historic negative patterns. Engel and Korf (2005) notes that suspicions among communities that the Forest guards' chairperson from another village is supporting forest office interests over this village's interests. Structural conflict arises from structural inequalities in control, ownership, power, authority or geographic separation. These issues may affect the determination of appropriate management processes, rules, roles and power that must be applied in addressing conflicts or managing the natural resources sustainably. A typology of conflict is useful when the issues in a conflict are centralized in one of the five categories. When issue focus occurs, different responses to conflicts are required. For example, if a conflict is primarily a data conflict, sharing 
information and being sure that each party is interpreting the facts the same way is useful. However, if the conflict primarily is about values, sharing factual data alone will be of little or no use.

\subsubsection{Levels of Conflict}

According to the FAO (2000), natural resource conflicts occur at various levels and involve a variety of actors. They range from conflicts among local men and women over the use of trees, to conflicts among neighbouring communities disputing control over woodland, to villages, community-based organizations, domestic and multinational businesses, governments, international development agencies and NGOs in conflict over the use and management of large forest tracts. Grimble and Wellard, (1997 cited in Warner, 2000) aid in classifying these levels into micro-micro conflict and micro-macro conflict. The micro-micro conflict occurs at the intrapersonal, interpersonal, and intergroup; inter community levels, while the micro-macro conflict occurs between the community level and external stakeholders such as state agencies, multinational organisations.

\subsubsection{Nature of Conflict}

Regarding the nature, conflicts may be classified into violent and nonviolent conflict or into constructive and destructive conflicts (Collins, 2008). The destructive conflicts are characterized by verbal and nonverbal insults, ego attacks, inflexibility, a mind-set of retaliation, and an exchange of negative emotion. These conflicts are also known as affective conflicts, or personalized conflicts, because they are personal in nature and characterized by negative emotions, tension, personality clashes, and defensiveness. In a particular case there can be a combination of acts of omission and acts of commission. The outcomes of these conflicts are often a damaged relationship.

Traditional views of conflict blame troublemakers and authorities, and fail to acknowledge the role of conflict as an integral part of change that can create opportunities for increased trust, relational growth, and joint problem solving (Collins, 2008:5). The focus on preventing or managing conflict has given way to the notion that conflict can be constructive and there is an optimal level of conflict in an organization that is better than no conflict at all. According to Collins, (2008:5) constructive conflicts are characterized by arguments about facts, information, ideas, or plans. The benefits of optimal levels of constructive conflict include better decisions and innovative approaches to solving problems.

Berghof Foundation (2012:117) described non-violence as both a philosophy, upholding the view that the use of force is both morally and politically illegitimate and counterproductive, and as a practice to achieve social change and express resistance to oppression. According to Sharp (n.d) one of the leading scholars in non-violent conflict action can take the form of protest, non-cooperation, and intervention in which the actionists, without employing physical violence, refuse to do certain things which they are expected, or required, to do; or do certain things which they are not expected, or are forbidden, to do.

\section{Materials and Methods}

\subsection{Site Description}

The study focused on KSNR, the only reserve designated as a Strict Nature Reserve and one of the two reserves situated in the transitional vegetation zone between the Guinea savanna and Forest regions of Ghana. The Kogyae Strict Nature Reserve is located in the Sekyere Central District (see Figure 1). The Reserve lies $25 \mathrm{~km}$ South-east of Ejura and 50km North-east of Mampong at the north-eastern part of the Ashanti Region. The $405 \mathrm{~km}^{2} \mathrm{KKSNR}$ lies within longitudes $0^{\circ} 05^{\prime}$ and $1^{\circ} 30^{\prime} \mathrm{W}$ and latitudes $6^{\circ} 55^{\prime}$ and $7^{0} 30^{\prime} \mathrm{N}$ in the Afram Plains.

The KSNR is a nature preservation area set up to protect the ecology, retain the transitional vegetation and fauna for scientific research and for monitoring the southward advancement of the savanna vegetation. Other aims include protecting the watersheds of the tributaries of the Sene and Afram rivers and providing timber products (Wildlife Division, 1994). Historically, the area constitutes the site where the two traditional areas, Kumawu and Kwaman, by treaty joined forces to fight invading enemies in one of their last victorious tribal wars. The area therefore is held as a sacred place for both traditional areas and each lays claim to it (Hagan, 1998). According to the Wildlife Division of the Forestry Commission (2002), the KSNR is the extended version of the former Kujani Forest Reserve (KFR), then under the Forestry Department. In 1971, the administration of the forest reserve was handed over to the Wildlife Division (WD) for strict protection under the Wildlife Reserve Regulations, Legislative Instrument (LI) 710. The KFR boundaries were extended to obtain a viable ecological unit for the KSNR. This became necessary since studies conducted by the WD indicated that, in the dry season the animals in the reserve depended on the rivers in the unprotected areas for survival.

The KSNR is however surrounded by a large human population who depend on agriculture for their livelihoods. These agricultural activities include crop farming, livestock farming, hunting, lumbering and fishing. For effective management, KSNR has been zoned into four major land-uses namely the Protected Areas (PA), 
Special Use Zone (SUZ), Restoration Zone (RZ) and Development Zone (DZ). Table 1 indicates the proportions of the land-uses in the KSNR. The PA is the largest land-use in the KSNR. It constitutes $220 \mathrm{~km}^{2}$, and represents 57 percent of the KSNR. This area of the reserve represents the most important and least disturbed habitats of the KSNR. The SUZ constitutes $98 \mathrm{~km}^{2}$ and represents 20 percent of the KSNR. The SUZ is a land-use practice that is not compatible with conservation activities but has been forced on management as a compromise with the local communities to resolve certain conflicts as a result of the boundary extension.

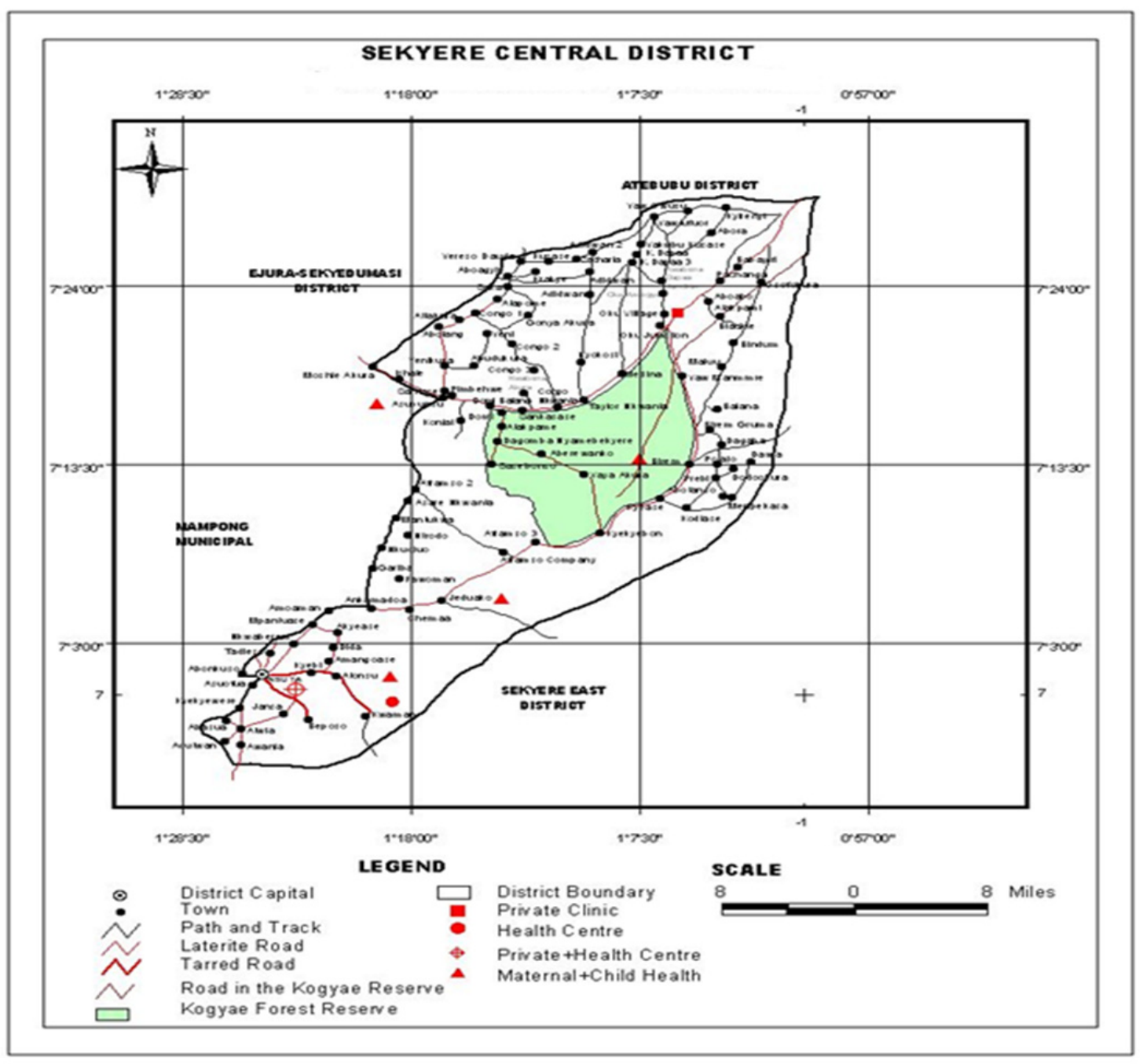

Figure 1. Kogyae Strict Nature Reserve in the Sekyere Central District

Source: Town and Country Planning Department, SCD, 2014.

Table 1. Proportion of land-uses of the KSNR

\begin{tabular}{lllll}
\hline Land-uses & Protected Area & Special Use Zone & Development Zone & Restoration Zone \\
\hline Land size & $220 \mathrm{~km}^{2}$ & $98 \mathrm{~km}^{2}$ & $1 \mathrm{~km}^{2}$ & $86 \mathrm{~km}^{2}$ \\
Percentage & 57 & 20 & 1 & 22 \\
\hline
\end{tabular}

Source: Wildlife Division of the Forestry Commission, (2002).

Other land-uses of the KSNR are the DZ and the RZ constituting $1 \mathrm{~km}$ and $86 \mathrm{~km}$ representing 1 percent and 22 percent respectively. Figure 3.3 shows the land-uses of the KSNR. 


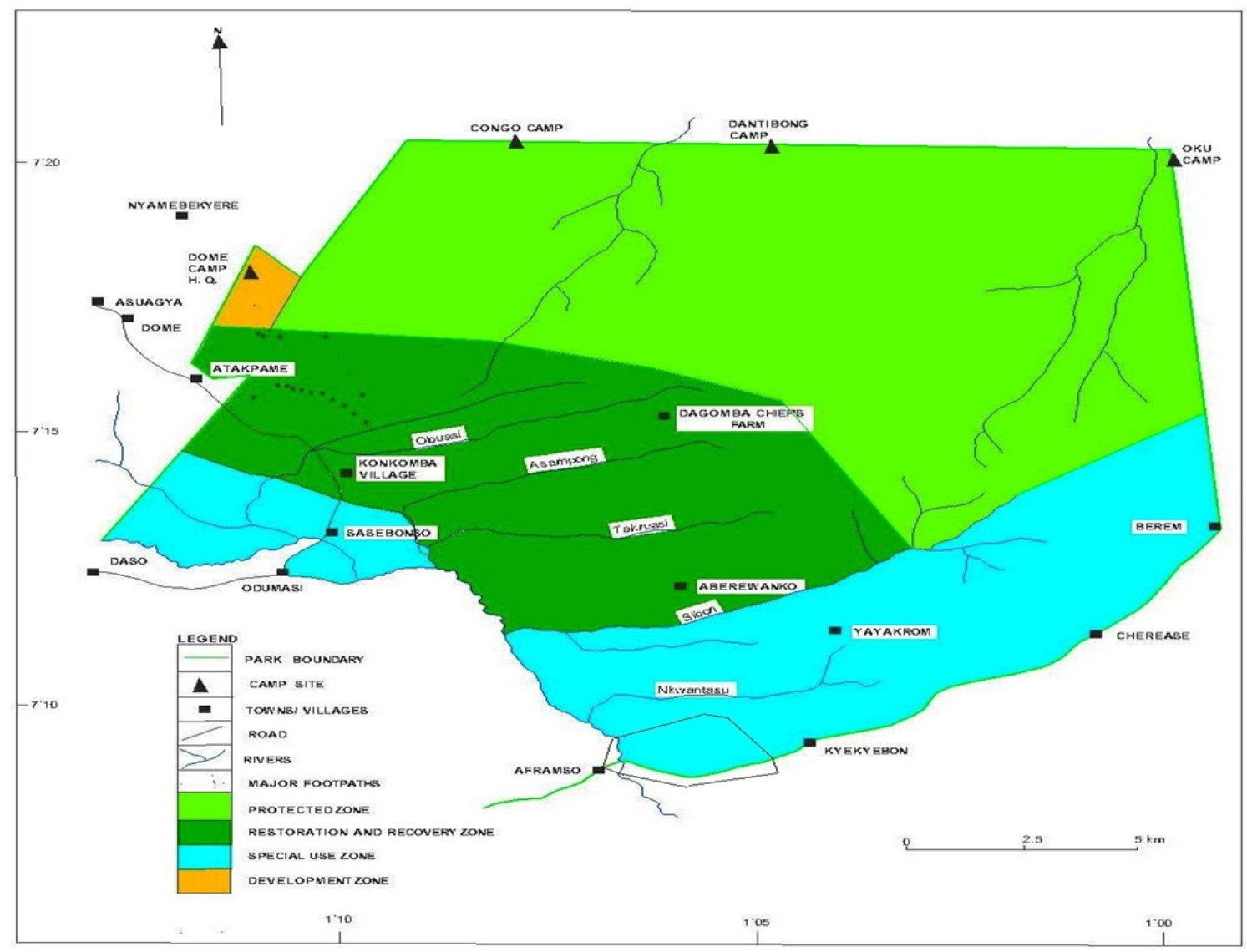

Figure 2. Land-uses of the KSNR

Source: Wildlife Division of the Forestry Commission (2002).

\subsection{Methods}

The Kogyae Strict Nature Reserve was used as a case study to better appreciate the phenomenon under investigation in the Ghanaian context. To do this, quantitative and qualitative approaches in terms of data needs were used in the study. The new field of study as well as its exploratory nature demanded a more flexible and open research design rather than one that is highly structured and rigid.

Empirical data were collected from multiple units of enquiry for this study through the administering of questionnaires, interview guide and observations between November, 2013 and May, 2014. In all, 100 heads of households were interviewed as well as four community leaders and two WD officers. The questionnaires were used to solicit information from the households while the interview guide helped collect data from the WD officers and the community leaders. The secondary data were obtained from published documents, reports, journals, periodicals, the Internet, magazines, newspapers, national and other relevant state documents on sustainable management of forest ecosystems. Unit committee members, Assembly members, Traditional Authorities, households, Wildlife Division staff among others were the main sources from which primary data for this study were collected. They provided insight into the origin, levels, types, nature and effects of the conflicts on development. Several inputs were made into how the conflicts were managed. Primary data in qualitative nature were also obtained from the heads of the institutions. Such data explained the reasons accounting for the trend and patterns observed in the secondary data. Secondary data obtained from the institutions included the Wildlife Division, the Agricultural Development Unit, the Police Service, District Security Council and Non-Government Organisations (World Vision International) in the district. The dynamism of the whole process was spiced up by the different temperaments of the participants. Different ideas were brought from different angles with different interpretations. The analysis of data proceeded in three stages: identification of themes, descriptive accounts and interpretative analyses. Based on the research questions, themes were identified from the data and derived inductively from the theoretical framework. The identified 
themes were given meaning through descriptive account and interpretative analyses. The themes were analysed and presented in the words of the households and in some cases, direct quotes were used to embody the voices of all identified and interviewed stakeholders. This ensured a more reliable and credible research findings.

\section{Results and Discussions}

\subsection{Age-Sex Characteristics of Households}

About 52.3 per cent of the respondents surveyed were females while 47.9 per cent were males. With respect to the age structure, majority of the respondents were within the economic active group (20-59). This constituted 84 percent of the respondents while the aged constituted 16 percent.

\subsection{Household Size}

Majority (43.9 percent) of the households surveyed had household size of between 6-9 members, 34 percent had 2-5 members, 16.9 percent had 10-13 member while 5.1 percent above 15 members. The current average household size for the study area is 7.9. This is higher than the current Sekyere Central District and National average household size figures of 6.4 and 4.6 respectively. The implication is that each household has a large number of dependants to feed, clothe and house. This will cause the demand for a lot of resources to maintain each household. However given the limited land resources in the SUZ to expand their farming activities, household heads poach for extra lands for farming and housing and logs as building materials for accommodation in the KSNR.

\subsection{Education Levels}

There was the need for the study to examine the educational status of the households as other researchers have established that demographic factors are major contributors to conflicts in the natural resource areas (EU-UN, 2012; Engel and Korf, 2005; DFID, 2001). The educational status of the households was also computed for the survey. Table 2 indicates that 48 percent of the households did not have any form of formal education. While 36 percent, 11 percent and 5 percent had elementary, secondary and tertiary level of education respectively. Those without any form of formal education (48 percent) gave reasons for their non-completion and non-attendance of any stage of their educational life as basically financial, poor academic performance and lack of interest.

Table 2. Educational Status of the Households in the KSNR

\begin{tabular}{ll}
\hline Level of education & Percentage of respondents \\
\hline Elementary & 36 \\
Secondary & 11 \\
Tertiary & 5 \\
No schooling & 48 \\
Total & 100 \\
\hline
\end{tabular}

Source: Field Survey, April, 2014.

The lack of education among the majority of the people in the host communities affirms their general perception of the reserve as potential farm land which should be released to them, especially the savanna section which they claim is very suitable for the production of yam and other food crops. To them it is a waste of arable land to maintain the areas as a reserve. Consequently, some indigenes on the south eastern part of the reserve continue to lease land to settlers for the cultivation of food crops. The survey also revealed that the people lack the requisite education that would enable them to compete effectively for jobs in the formal sector. The people again lack the required occupational skills that would allow them to venture into different types of alternative livelihood activities. The high illiteracy rate among the people could also affect their appreciation and support for conservational policies in the KSNR.

\subsection{Sources of Livelihood Activities}

Agricultural activities were mainly observed as the source of livelihood for the households in the host communities of the KSNR. These activities were mainly farming, hunting and gathering, fuel wood collection, charcoal burning, logging and palm wine tapping. Table 3 indicates the proportions of the households engaged in the agricultural activities. 
Table 3. Livelihood Activities of Households in the KSNR

\begin{tabular}{ll}
\hline Activities & Percentage of respondents \\
\hline Farming & 97 \\
Hunting and gathering & 62 \\
Fuel wood collection & 89 \\
Medicinal plant collection & 59 \\
Charcoal making & 29 \\
Arts and craft material & 11 \\
Logging & 46 \\
Palm wine tapping & 18 \\
\hline
\end{tabular}

Source: Field Survey, April, 2014.

*percentages sum up to more than 100 percent because all respondents were to respond to all the activities listed.

From Table 3, it is evident that the major occupation of the respondents of the host communities (97 percent) is farming while 89 percent were engaged in fuel wood collection as the main source of energy for cooking. Farming was observed to be done on subsistence level with poor farming practices such as slash and burn being practiced. Almost all the above livelihood activities of the host communities were illegal activities in natural reserves especially in strict nature reserve in Ghana according to the Wildlife Reserve Regulations of 1971, LI 710. However, attempts by the WD to enforce these natural resource laws have been perceived as a way of impoverishing and marginalising the members of the host communities. Desperations among the members of these host communities to maintain their rights and control of the KSNR consequently results in conflicts in the KSNR.

\subsection{Household Income Levels}

It was necessary to identify the income level of the households to determine whether their livelihood sources were enough to support their basic needs. About 29 percent of households were earning income between GH $\phi 4001.00$ - GH $\phi 6000.00$ while 23 percent were earning income level below GH $\phi 2000.00$ per annum (see Table 4). The average annual income level of households computed was GH $\notin 600.32$. This was lower than both the district and national average annual income level of GH\&730.20 and $\mathrm{GH} \phi 1,217.00$ respectively.

Table 4. Income level of Households in the Host communities

\begin{tabular}{ll}
\hline Income levels & Percentage of respondents \\
Below GH $\varnothing 2000.00$ & 23 \\
GH $\varnothing 2001.00-\mathrm{GH} \phi 4000.00$ & 17 \\
GH $\varnothing 4001.00-\mathrm{GH} \phi 6000.00$ & 29 \\
GH $\varnothing 6001.00-\mathrm{GH} \phi 8000.00$ & 15 \\
GH $\varnothing 10001$ and above & 10 \\
Total & 100 \\
\hline
\end{tabular}

Source: Field Survey, $201 \overline{.}$

The low income level of the people partly explains their continual dependency on the agricultural activities since little capital is required to finance these agricultural activities. Local people in these host communities are left with nothing to save or even access the National Health Insurance Scheme. This could probably explain the over 50 percent of the households' dependence on medicinal plant collection in the KSNR for their medical reasons.

4.6 Origin, Types, Levels and Nature of Conflicts

Assessing the types, origin, nature and levels of conflict enable one to better appreciate the root causes and dynamics of conflict, as well as the opportunities for peace. 


\subsubsection{Types of Conflicts in the KSNR}

Based on the typology of conflicts by Moore (1996), three main types of conflicts were identified namely structural conflict, data conflict and interest conflicts in the KSNR.

A structural conflict was the main type that characterised the KSNR. According to Moore (1996) such conflicts arise when there are structural inequalities in control, ownership, power, authority, institutional limitations or geographic separation. Weak enforcement of resource laws, land litigation and demographic changes were identified as the main causes of this structural conflict in the KNSR. The improper structures to effectively regulate the operations of the KSNR have been the major triggers of conflicts among the people in the host communities and with the WD. There is therefore no harmony and cooperation among these stakeholders to ensure the conservation of the KSNR.

Data conflict is also another type of conflict characterising the KSNR. This type of conflict arises when information is lacking, differently interpreted or withheld by one party from the other party. Natural resource policies and interventions were formulated without the active and sustained participation of members of the host communities and other stakeholders such DADU, WVI-Ghana, Ghana Education Service, Ghana Health Service and Religious bodies. Consequently these unaware stakeholders continued their activities which were illegal according to the Wildlife Reserve Regulations of 1971, LI 710 and hence generating conflicts. DADU in its ignorance has continually supported farmers in the host communities to expand their farm size which eventually encroached on the KSNR. The head of one of these communities (Nyamebekyere Dagomba) was judged the best Ashanti Regional Yam farmer in 1991. Since then he has farmed so extensively that the original protected area is seriously threatened. WVI-Ghana has also continually provided some social amenities such as bore holes, primary schools etc which are located in the KSNR. The consequence was the constant confrontations that are mostly violent especially when the WD makes attempts to destroy farms of the members of the host communities and the investments that the other stakeholders have made in the KSNR.

The third and last type of conflict observed in the KSNR was the interest conflict. This occurs when there are actual or perceived scarce resources such as physical assets. This has resulted in competition between different users such as the Wildlife Division, Traditional Authorities, District Agricultural Development Unit, settlers and households of the host communities to capture or protect specific resources for their various interests or activities. The forceful eviction of the host communities especially by the WD has generally resulted into conflicts.

\subsubsection{Origin of Conflict in the KSNR}

Several factors were identified as the causes of conflicts in the KSNR. Among these causes (see Table 5), household heads interviewed attributed imposition of policy without effective participation of stakeholders, inadequate source of livelihood and demographic change as the immediate source of conflict respectively in the KSNR.

Table 5. Sources of conflict in the KSNR

\begin{tabular}{cc}
\hline Factors & Percentage of respondents \\
\hline DC & 18 \\
LL & 11 \\
ISL & 25 \\
WERL & 9 \\
IPEPS & 37 \\
Total & 100 \\
\hline
\end{tabular}

Source: Field Survey. April, 2014.

*DC - Demographic change LL - Land litigations WERL-Weak enforcement of Resource laws ISLInadequate source of livelihood IPEPS - Imposition of policy without effective participation of stakeholders.

Table 5 indicates that 37 percent out of the 100 households identified IPEPS as the main source of conflicts in the KSNR. The host communities of the KSNR and other state institutions such as District Agricultural Development Unit (DADU) and development partners such as WVI-Ghana claimed their unawareness of the 
policy change of the former Kujani Forest Reserve to the KSNR until later years. Consequently, these ignorant stakeholders such as the state agencies endorsed the right of the indigenes and the settlers whom efforts are made to be evicted to perpetuate their stay and engagement in unrestrained farming activities in the KSNR. This mostly resulted into conflicts with the Wildlife Guards (WGs). The situation in the KSNR confirms Nang et al. (2011) postulation that poor stakeholder analysis in natural resource management is the major causes of conflicts over natural reserves.

Again, 25 percent of the households also revealed that the causes of conflict were the inadequate source of livelihood (ISL) in the KSNR. It was evident from the field survey that 97 percent out of the 100 households depended on farming for their livelihood. While 89 percent, 62 percent, 59 percent, 46 percent and 35 percent, of the households undertook fuel wood collection, hunting and gathering, medicinal plant collection, logging and charcoal making activities respectively to support their livelihood (see Table 4). However, the creation of the KSNR necessitated the extension of the original boundaries of the reserve to obtain an ecological unit suitable for the conservation of the wildlife. This action according to the households claimed most of the farmlands as well as some part of their built environment without any corresponding provision of alternative livelihood support for the affected people. According to the respondents they had no other option than to fall back on the KSNR for survival. In addition, the WD also revealed that the people lack the needed funds to train and establish themselves in the alternative livelihood activities that were identified with them. This has resulted in their over dependence on farming, petty trading and other activities in the KSNR to make a living.

In addition to the sources of conflicts, Table 5 indicated that $18 \%$ of the households associated demographic change as another cause of conflicts in the KSNR. According to the households, the increase in population for the past 16 years has not seen any extension on the Special Use Zone (SUZ) from which their livelihoods depended. This was evident from the increase in average household size from 3.2 in 1998 to 7.9 in 2014.

The increase in the household size implies that household heads whose entire source of livelihood depends on the SUZ will have much greater responsibility in ensuring quality education for their children, health and food security.

Other factors observed from the households from which conflicts were emanating from included:

- land litigations between the Kumawu Traditional Council and the Kwaman Traditional Councils over the KSNR and

- weak enforcement of resources laws due to low capacity of the WD and Traditional Authority and political influences. This was evidenced from the number of poachers observed (301) as against the number of poachers arrested (76).

\subsubsection{Conflicting Items in the KSNR}

The Heidelberg Institute for International Conflict Research (2010) underscores conflicting item as the units or substance around which conflicts are triggered. They are thus the objects of interest around which positions are taken by stakeholders. From the field survey land ( 86 percent), timber ( 75 percent), water ( 72 percent) and game (percent) were the major items around which these conflicts were occurring according to the households (see table 6). This finding corroborates Anderson et al. (1996) and Ayling and Kelly's (1997) assertion on conflicting items usually fought over in natural resource areas.

Table 6. Conflicting Items in the KSNR

\begin{tabular}{cc}
\hline Conflicting items & Percentage of respondents \\
\hline Land & 86 \\
Water & 72 \\
Game & 75 \\
Timber & 62 \\
\hline
\end{tabular}

Source: Field Survey. April, 2014.

*percentages sum up to more than 100 because all respondents were supposed to respond to all the conflicting items.

The demand for land especially for farming among community members continues to serve as a major conflict in the KSNR. With high average household size of 7.9, loss of soil fertility and influx of migrants to the host 
communities continue to exert high pressure on the available limited fertile lands in the SUZ. With farming as the major economic activity, the struggle over these lands becomes worse off during the farming season in the SUZ which has not been adjusted to accommodate needs of the current population. The current loss of soil fertility in the SUZ encourages encroachments in the protected area of the KSNR which serve as a source of conflicts between the WD and the communities.

Conflicts over water resource are intensified during the dry season especially when the inadequate boreholes fail to supply water to meet the domestic needs of the host communities. Without any other source of water supply during such seasons, the community members fall back to the river bodies in the protected area of the KSNR as alternative source of drinking water.

Incidence of poacher's activities in the KSNR was estimated to be 301 according to the 2012 Annual Wildlife Division Report. This was evidenced by the numerous spent cartridges, carbide, gin traps and wire snares that were observed. However, hunting on commercial basis by the indigenous people has generally declined even though the settlers trap animals for domestic consumption. Group hunting using dogs is also carried out in and around the reserve in the dry season with the resultant escalation of bushfires. Equipment usually used during such hunting expeditions includes clubs, cutlasses and rarely guns especially in the SUZ though such activities are forbidden. There have been several occasions where staff of the Wildlife Division have been assaulted and beaten up for trying to arrest poachers. Wild animals that are hunted include Duikers, Antelopes, Bushbuck and Deer. Other small mammals include African Giant Rat, Grass Cutter, Palm Squirrel and other rodents.

Commercial charcoal making is taking place throughout the reserve where farming is taking place. Though farmers are not allowed to cut trees in the SUZ by any means especially with chainsaw machines, they rather set pockets of fire at roots of the trees so as to get the taproots weakened. Dead trees that have been left over after farming are usually used for charcoal burning. Poaching of timber trees by logging companies and individuals occurs in the southern part of the reserve.

\subsubsection{Levels of the Conflicts in the KSNR}

The conflict in the KSNR has taken several levels. Two basic levels of conflicts were identified during the survey. These two were commonly found among the community members themselves and between the community members and the WD. To go by the categorizations of the levels by Grimble and Wellard (1997), the micro-micro conflicts and micro-macro conflicts levels will be used for analysis. About 66 percent of the households interviewed claimed that conflicts were mostly observed at the micro-macro level (that is between the WD and the community members) while 33 percent of the households indicated a micro-micro conflict level in the KSNR.

Conflict at the micro-micro level resulted from struggles for fertile lands for farming in the SUZ. The failure to share lands that were allotted to the communities among the households as intended in the Action Plan for Biodiversity Conservation and Sustainable Livelihood in the SUZ explains the conflicts at the community levels. Another source of conflicts among the community members is the failure of the Community Conflict Management Committee (CCMC) in sharing the lands in the SUZ to the households of the host communities as determined by the Memorandum of Understanding (MOU) arrived under the WVI conflict management initiative. Consequently, households had to struggle among themselves in order to obtain some portions of the SUZ to farm. The situation had degenerated into deep conflicts resulting in social break downs among the community members. This conflict situation confirms the conflict perspective theory which postulates that the loss of other groups (households) due to the scarcity of farmlands in the SUZ may serve as a source of conflict.

Micro -macro conflict level on the other hand occurred between the community members and outsiders. From the survey, the main outsider in conflicts with the community members was the WD. The presence of the WD has served as a major obstacle to the community members in accessing resources from the SUZ and the protected area in the KSNR. There are restrictions such as not growing tree crops, hunting and gathering, logging by the community members in the reserve. Community members who are caught violating these regulations are arrested by Wildlife Guards and handed over to the Police for prosecution. The WD is able to track illegal activities in the KSNR through patrolling and informants in the communities. Tensions usually become high when the Traditional Authorities refuse to release these culprits to the WD for arrest and prosecution

\subsubsection{Nature of the Conflicts in the KSNR}

The nature of conflict in the KSNR has taken varying forms. From the survey, varying opinions were given with regards to the nature of the conflict. The forms of the nature of the conflict have been a mixture of non-violent and violent conflicts. This is presented in Table 7. Intervention was the most frequent dimension of the 
non-violent conflict while environmental damage and economic damage represented the most dimensions of the violent conflict.

Table 7. Nature of Conflicts in the KSNR

\begin{tabular}{lc}
\hline Forms of conflict & Percentage of respondents \\
\hline Non-violent Conflict & 21 \\
Intervention & 10 \\
Non-cooperative & 14 \\
Protest & \\
Violent conflict & 4 \\
Physical damage & 22 \\
Economic damage & 23 \\
Environmental damage & 6 \\
Social damage & 100 \\
Total &
\end{tabular}

Source: Field Survey, April, 2014.

The most observed way in which all stakeholders have adopted to make conflicts in KNSR constructive or non-violent is lobbying which has received the most intervention from the government. The community leaders mostly lobby through the politicians to get their positions achieved. An example of such a political lobby was when the President of Ghana in 1993 gave a directive to an amicable solution to be reached when the communities were threatened with eviction by the WDs. The lobby resulted in the re-adjustment of the boundary of the KSNR for the communities to have access to the lands to farm in the KSNR. The WD has achieved some level of constructive conflict through traditional lobbying. These are done through the Paramount Chief of Kwaman to tone down agitations from sub-chiefs in the host communities of the KSNR.

Notwithstanding, environmental damage, a dimension of violent conflict also occurred when some aggrieved section of the people of the host communities felt that the WD was insensitive to their needs or plight in emergence situations especially when an official request has been made. An instance was when in 2012, some victims of fire in Asaasebonso requested for logs from the protected area (PA) to reconstruct their ruined houses. However, their request was not granted by the WD. This provoked the victims to poach for logs in excess. The uncontrolled logging resulted in deforestation and loss of most economic trees and limited species. Hunters who were not allowed into the protected area sometimes set some part of the protected area on fire to drive the animals to areas where they could be killed.

Economic damage that occurred from the violent conflicts in the KSNR involved the destruction of farms in the protected area of the KSNR by the community members. An example of such an economic damage was when in 2008, a whole community maize farm by the people of Birem in the protected area of the KSNR was destroyed by the WD. When a section of the people was asked the reasons for such a venture in the KSNR, they claimed most of their fertile farmlands were absorbed by KSNR during the extension of the boundaries and as such had limited lands to do farming. Hunting and gathering and charcoal products obtained from the KNSR are also seized or destroyed by WD. Victims of such activities especially the charcoal producers eventually lose their investments. The seizure is done to discourage the reoccurrence of such incidence. However, economic damage is on the low level in Dome and Chiriase because most of their farmlands are not in the KSNR.

Other dimensions of both non-violent and violent conflict observed in the KSNR were protest, non-cooperation, social damage and physical damage. One can therefore conclude that the high non-violent nature of the host communities is a positive indication of their willingness to participate in a constructive conflict resolution over the KSNR.

\subsection{Effects of the Conflicts in Development}

The indigenous people concede that the reserve exerts enormous influence on the environment in general and rainfall in particular. It also protects wild animals which otherwise would have been non-existent in the area, to 
the disadvantage of future generations. The reserve has also contributed enormously to significant research both locally and internationally. However, the conflict situation has had negative impacts on the livelihood of the people in the host communities, the management of the KSNR and on the environment.

On the livelihood consequence, the conflict between the host communities and the WD has constantly resulted in the destruction of farms that were undertaken in the protected area of the KSNR by the community members. The temptation for encroaching on the KSNR for their farm activities is due to the reduction in the total farm lands of the host communities from $185 \mathrm{~km}^{2}$ to $98 \mathrm{~km}^{2}$. This represents 52.9 percent reduction in the total farm land size of the host communities whose main livelihood depended on farming. The situation is compounded when for the past 16 years the size of SUZ has not been re-adjustment in the form of extending its size to accommodate the current needs of the increase in population. This could partly explain why their annual average income of household of the host communities' is 21.6 percent and 102.7 percent lower than the district and national annual average income respectively. Household heads with the current average household size of 7.9 are currently overburdened, a situation that is also affirmed by Anderson et al. (1996); Ayling and Kelly (1997) in natural resource areas.

Restrictions of the host communities by the WD from accessing the river bodies affects the water supply of the people especially during the dry season where the inadequate boreholes are not able to supply them with enough water. The effect has been the outbreak of diseases such as cholera and other water borne disease. In conclusion, it can be said that the main challenge in meeting the livelihood needs of the host communities is employment opportunities.

On the issues of the effect of the conflict on the management of the KSNR, the unresolved litigation over the lands in the KSNR between the two Paramount Chiefs (Kwaman and Kumawu Traditional Councils) coupled with nonpayment of compensation have resulted into a low sense of commitment of the Traditional Authorities to supporting the WD in the management of the KSNR. They see the reserve as potential farm land which should be released to them; especially the savanna section which they claim is very suitable for the production of yam and other food crops. To them it is a waste of arable land to maintain the areas as a reserve. Consequently, some indigenes on the south eastern part of the reserve continue to lease land to settlers for the cultivation of food crops.

Another effect of the conflict on the management of the KSNR is the present boundary of the reserve. The host communities recognise only the boundary of the former Kujani Bush Forest Reserve which presently represents the protected area in the KSNR. Ironically, the present boundary passes through communities like Berem, Chichibon and Cheriase, with the result that some of the inhabitants in these communities live inside the reserve. This state of affairs has led to the present uncontrolled use of the reserve land for farming, timber logging, charcoal making and akpeteshie distilling.

The vegetation of the KSNR is fast becoming degraded. It was evident from the survey that the forest and farmlands have been destroyed due to fast depletion of trees for charcoal production, poor farming practices, timber operations, and bush fires. Shifting cultivation was observed as the farming practice by the farmers. Farmers frequently shifted from land to land due the financial incapacity to procure and apply agro-chemicals to enrich the soil. The fallow period has reduced to 2-3 years. The consequence is the break in the resilience in the KSNR ecosystem. The trees are continuously logged especially within the SUZ for charcoal production which consequently results in high incidence of bushfire especially in the SUZ of the KSNR. Spots of the charcoal site become channels for erosion which degrades the land. According to the WD, the fragmentation of habitat, local disappearance of native species and invasion by exotic weeds and other plants are some of the other ecological consequences of shifting agriculture in the KSNR.

The KSNR also serves as the source for some major rivers such as the Afram. The river faces a great threat from the extensive farming which is systematically destroying its forest cover. The Afram, which used to flow regularly throughout the year breaks into pockets of pools during the dry season. Afram is one of the major rivers that flow into the Volta River which supplies water to the hydro-electric dams at Akosombo and Kpong. Threats to the Afram will have a devastating effect on power generation at the two dams.

\section{Conclusion and Recommendation}

When natural resources are put under reserve in poverty-dominated regions, there is always the conflict between the resource users expecting the reserve to continually provide its services to sustain their livelihood and the resource managers seeking to protect the overall health of the ecosystem through sustainable extraction of its resources. This was the case with the KSNR and the host communities of the Reserve. 
In this study, the imposition of policy without effective participation by stakeholders, inadequate alternative livelihood activities, demographic change for the people in the host communities have increased the dependence these communities on the KSNR to meet their livelihood needs. In these Communities, the ecosystem services from the KSNR constitute a direct life-blood for the majority of the people. While the major occupation of the people of host communities is farming, this activity does not fetch them enough returns to meet their livelihood needs due to strict regulations governing strict nature reserves in Ghana. The situation has resulted into a mixture of violent and nonviolent conflicts between the host communities and the WD. Conflicts have also been observed among the community members due to the limited access to land, water, timber, game etc. However, with weak enforcement of resources, the tension in the area keeps on increasing between the WD and host communities due to uncontrolled exploitation of the natural resources in the KSNR.

Despite several interventions to address these conflicts, minimal success has been attained. This was due to poor stakeholder analysis and participation, low financial capacity to implement conflict resolutions measures, lack of legislative instrument to enforce a well-structured conflict mechanism. The WD has adopted the force strategy to keep the peoples' illegal activities from the reserve while the communities have also adopted withdrawal strategy to stay away from any conflict management mechanism initiated by the WD such as the PAMAB.

An important way forward to resolve some of these issues would be for the Ministry of Lands and Natural Resource to ensure that legislation is enacted to support collaborative natural resource management in Ghana. This will go a long way to ensure support for a well-structured conflict management mechanism aimed at ensuring proper cooperation between managers and resource users. There is also the need for such a legislation to consider allocating a sustainable portion of benefits accruing from resource management towards the development of host communities.

There exists a complex system of ecosystem and human well-being linkages that require multi-disciplinary approaches to fully appreciate. There is the need to understand these ecosystem-human-well-being linkages through proper information dissemination and management without treating the different aspects as independent. When this is done, the distribution of benefits from forest resources and people's impact on ecosystem services will be clearly understood. It is therefore important for the Office of Administration of Stool Lands (OASL) and the WD to collaborate to ensure that structures are established to ensure that there is accountability and transparency in the distribution of the resource benefits.

Deliberate actions should be taken to strengthen the WD to embark on educational activities in natural reserve host communities. These educational efforts should be aimed at sensitizing the community on sustainable forest management issues. To this end, the communities will be informed and local/indigenous knowledge on sustainable natural resource management practices enhanced.

Concerted efforts should be made by the Sekyere Central District Assembly to identify alternative livelihood activities within the KSNR host communities. This will help reduce their dependence on the natural resources and thereby improve the livelihood conditions of the host communities while maintaining the overall health of the ecosystem services. There is also the need to build the capacity of KSNR host communities and support them in exploring alternative livelihood interventions that are sustainable and viable in meeting their livelihood needs as forest communities.

The Sekyere Central District Assembly should also ensure that all stakeholders are involved in various stages of natural resource policy formulation processes. Consideration should however be given to their stakes, roles and capacities. Developing an integrated approach to natural resource management with the involvement of all stakeholders is imperative. By so doing, a balance between three objectives - conservation, sustainable use and fair, and equitable sharing of the benefits arising out of the utilization of the forest as proposed by the Convention on Biodiversity will be achieved. Multi-stakeholder forums should be continually held in this direction to help build confidence among the different stakeholders.

Efforts should be made to strengthen the capacity of local government institutions such as the WD, DADU among others in promoting the sustainable utilization and management of the social and economic benefits from natural resources. Community level governance should be enhanced to ensure that benefits received are used in an open, transparent and accountable manner. Community level institutions should therefore be well equipped to directly receive, plan for and utilize these resources.

There is the need therefore to ensure a collaborative approach towards sustainable conflict management through consultation, needs assessment, investigation, synthesis and consensus building. When this is done, there will be equity and fair distribution of benefits and a better collaboration among the stakeholders to ensure efficiency in the execution of sustainable utilization and management of the KSNR. 


\section{References}

Alao A. (2011). Natural Resources and the Dynamics of Conflicts in West Africa. In T. Jaye, D. Garuda, \& S. Amadi (Eds.), ECOWAS and Dynamics of Conflict and Peace-building. Dakar CODESRIA. Retrieved October 20, 2013 from www.codesria.org/spip.php/article1534

Anderson, J., Gauthier, M., Thomas, G., \& Wondolleck, J. (1996). Setting the stage. Presented at the Global Conference on Addressing Natural Resource Conflict Through Community Forestry, Jan-Apr 1996. Forests, Trees and People Programme of the Food and Agriculture Organization of the United Nations, Rome, Italy.

Atta-Asamoah, A. (2010). Beyond Greed and Grievance: natural resource Characteristics and Conflict in Africa. Institute for Security Studies, Pretoria.

Ayivor, S. J., Gordon, C., \& Ntiamoa-Baidu, Y. (2013). Protected Area Management and Livelihood Conflicts in Ghana: A case study of Digya National Park. Institute for Environment and Sanitation Studies, University of Ghana, Legon, PARKS Vol. 19.1.

Ayling, R., \& Kelly, K. (1997). Dealing with conflict: natural resources and dispute resolution. Commonwealth Forestry Review. Retrieved September 13, 2013 from www.dhdi.free.fr/researches/environment/.../rout forestpluralism.htm

Bercovitch, J., Kremenyuk, V. A., \& Zartman, I. W. (2008). Introduction: The Nature of Conflict and Conflict Resolution. Sage Publications Ltd, London, UK. Retrieved October 20, 2013 from http://www.sagepub.com/upm-data/24632_Bercovitch Intro.pdf

Berghof Foundation. (2012). Bergh of Glossary on Conflict Transformation. 20 notions for theory and practice Berlin. Retrieved December 23, 2013 from www.berghof-foundation.org

Buckles, D., \& Rusnak, G. (2005). Conflict and collaboration in natural resource management. International Development Research Centre. Retrieved July 12, 2013 from http://idrc.org/en/ev-27964-201-1-DO_TOPIC

Collins, S. D. (2008). Module 3: Managing Conflict and Workplace Relationships. Volume 3 of Managerial Communication Series. Cengage Learning. Retrieved December 23, 2013 from www.books. google.com.gh/books?isbn=0324584199

Engel, A., \& Korf, B. (2005). Negotiation and mediation techniques for natural resource management. Prepared in the framework of the Livelihood Support Programme (LSP) An interdepartmental programme for improving support for enhancing livelihoods of the rural poor. Management Service, Information Division, FAO, Viale delle Terme di Caracalla, 00100 Rome, Italy.

EU-UN. (2012). Toolkit and Guidance for Preventing and Managing Land and Natural Resources Conflict Environmental Scarcity and Conflict. Renewable Resources and Conflicts United Nations Interagency Framework Team for Preventive Action

FAO. (2000). Conflict and Natural Resource Management. Food and Agriculture Organization of the United Nations. Retrieved October 25, 2013 from http://www.fao.org/forestry/21572-0d9d4b 43a5 6ac49880557f4ebaa3534e3.pdf

Garrett, N., \& Piccinni, A. (2012). Natural Resources and Conflict A New Security Challenge for the European Union. A Report for SIPRI by Resource Consulting Services

Hagan, J. E. (1998). The Kogyae Strict Nature Reserve. The World Bank/WBI's CBNRM Initiative, GIMPA, Accra. Retrieved August 15, 2013 from http://srdis.ciesin.columbia.edu/ cases/ghana-003.html

Hammill, A., \& Bescançon, C. (2010). Promoting Conflict Sensitivity in Transboundary Protected Areas: A Role for Peace and Conflict Impact Assessments. Paper prepared for the workshop on Transboundary Protected Areas in the Governance Stream of the 5th World Parks Congress, Durban, South Africa.

HIIK. (2010). Conflict Barometer 2010. Heidelberg Institute for International: Conflict Research. 19th Annual Conflict Analysis, University of Heidelberg. Retrieved September 20, 2013 from http://www.hiik.de/en/konfliktbarometer/pdf/ConflictBarometer_2010.pdf

Joy, K. J., \& Paranjape, S. (2009). Understanding Water Conflicts in South Asia. Society for Promoting Participative Ecosystem Management (SOPPECOM), Pune.

Lewis, C. (1996). Managing Conflicts in Protected Areas. IUCN, Gland, Switzerland, and Cambridge, UK. xii + $100 \mathrm{pp}$. 
Levy, C. (2009). Protected Areas: from vertical institutions to collaborative dynamics. Biophysical and socio-economic frame conditions for the sustainable management of natural resources. Retrieved May 22, 2014 from www.tropentag.de/.com

Ministry of Lands and Natural Resources. (2012). Ghana Forest and Wildlife Policy. Accra: Ministry of Land and Natural Resources

Nang, P., Khiev, D., Hirsch, P., \& Whitehead, I. (2011). Improving the Governance of Water Resources in Cambodia: A Stakeholder Analysis. CDRI Working Paper Series, no. 54. Phnom Penh: Cambodia Development Resource Institute.

Ramírez, R. (1999). Stakeholder Analysis and Conflict Management. A concept of society In D. Buckles (Ed.), Cultivating peace: Conflict and Collaboration in Natural Resource Management. International Development Research Centre, Ottawa, ON, Canada.

Roe, D., Nelson F., \& Sandbrook, C. (2009). Community management of natural resources in Africa Impacts, experiences and future directions. International Institute for Environment and Development (IIED), UK. Retrieved February 17, 2014 frrom http://pubs.iied.org/ pdfs/17503IIED.pdf

Schweithelm, J., Kanaan R., \& Yonzon, P. (2006). Conflict over Natural Resources at the Community Level in Nepal Including Its Relationship to Armed Conflict. ARD, Inc. United States Agency for International Development.

Sunderlin, W. D., Angelsen, A., Belcher, B., Burgers, P., Nasi, R., Santoso, L., \& Wunder, S. (2005). Livelihoods, forests, and conservation in developing countries: an overview. World development, 33(9), 1383-1402. http://dx.doi.org/10.1016/j.worlddev.2004.10.004

Warner, M. (2000). Conflict management in community-based natural resource projects: experiences From Fiji and Papua New Guinea Working Paper 135. Overseas Development Institute Portland House Stag Place London SW1E 5DP UK pg 9

Vondilia K. G. (2009). Do Ghanaian Farmers have preferences for the National Biodiversity Strategy? A case study of farmers living around the Kakum National Park in the Central Region. Ghana Policy Journal. Vol 3. The Institute of Economic Affairs, Accra. Ghana

Vondolia, G. K. (2009). Do Ghanian farmers have preferences for the National Biodiversity Strategy? A case study of farmers living around the Kakum National Park in the Central Region. Ghana Policy Journal, 3(August), 48-68.

World Trade Organisation (WTO). (2010). World Trade Report 2010 Trade in natural resources. Retrieved September 11, 2013 from www.wto.org/world_trade_report10_e.pdff

\section{Copyrights}

Copyright for this article is retained by the author(s), with first publication rights granted to the journal.

This is an open-access article distributed under the terms and conditions of the Creative Commons Attribution license (http://creativecommons.org/licenses/by/3.0/). 